\title{
Vegetation Composition, Biomass Production, Carrying Capacity and Grassland Types in Odolla Area of Shinile Zone, Eastern Ethiopia
}

\author{
Tessema Zewdu ${ }^{1}$ and Yvan Oustalet ${ }^{2}$ \\ ${ }^{1}$ Department of Animal Sciences, Haramaya Univesity, P O Box 138, Dire Dawa, Ethiopia \\ ${ }^{2}$ Handicap International, P O Box 2686, Dire Dawa, Ethiopia
}

\begin{abstract}
A study was conducted to characterize vegetation composition and grassland types as well as to estimate biomass production and carrying capacity of the rangeland in Ordolla areas of Shinile zone, eastern Ethiopia in October 2004. The Ordolla grasslands covered 22,621 ha on alluvial plain composed of sand and silt texture and clay in minor cases in small hydromorophic depressions. Seventeen vegetation types are identified in Orodolla areas based on soil types, vegetation structure and density, and drainage pattern described using LANDSAT image and geographical map of the area. The dominant grass species were Cynodon dactylon, Cynodon nlemfuensis, Eragrostis cilianensis, Cenchrus ciliaris, Andropogon greenwayii, Brachiaria leersiodes, Setaria pumila and Sorghum arundinaceum. Acacia tortilis, Acacia nilotica, Acacia mellifera and Acacia seyal were the most dominant shrubs with scattered Caddaba rotundifolia, Caddaba furmisa, Seddera bagshawei, Tamarix nilotica, Dobera glabra and abundant Parthenium hysterophorus, Cissus rotundifolia and $C$. quadrangularis. The grass biomass estimated in enclosed site near Ordolla village was $4.5 \mathrm{t} \mathrm{DM} / \mathrm{ha} / \mathrm{yr}$ and the total grass biomass produced in Ordolla rangeland was estimated around $27534 \mathrm{t}$ DM/year. The theoretical, dry and wet seasons carrying capacities were $0.16,0.06$ and 0.09 TLU/ha, respectively. There were good grazing lands in hydromorphic depression and well drained facets in Ordolla areas but the palatable grasses, trees and shrubs are decreasing due to overgrazing, runoff and drought and replaced by Parthenium, Calotropis, Solanum and Xanthium species, which are invader category of the plant community, indicating overgrazing and rangeland degradation.
\end{abstract}

Keywords: Biomass Production; Carrying Capacity; Grassland Types; Grazing Lands; Vegetation Composition

\section{Introduction}

The rangeland of Ethiopia covers about $60 \%$ of the total area (about 62 million ha) of which $88 \%$ receive less than $600 \mathrm{~mm}$ rainfall per year, and is the major source of livestock feed (BLPDP, 2004; PFE, 2004). The pastoral areas of Ethiopia are located around the peripheries almost surrounding the central mass below 1500 masl on degraded shallow soils and fallow lands, which cannot be successfully cropped because of physical constraints (Alemu and Lemma, 1991; Alemayehu, 1998)). They are characterized by lowland plains and have relatively harsh climate with low, unreliable and erratic rainfall and high temperature (Coppock, 1994). The grasslands include sparse vegetation of grasses, bushes, shrubs, small trees and bare land with low level of surface water. The pastoral areas are sparsely human populated and are occupied by temporary and seasonal settlements with semi nomadic pastoral transhumant mode of life (Coppock, 1994).

The Somali Region in Ethiopia is one of the pastoral areas of the country covering about $285,000 \mathrm{~km}^{2}$ and is divided into 9 administrative zones with 52 districts and the people depend on pastoral activity and in some extent agro pastoral agriculture (SORPARI, 2003). Evaluation and monitoring of rangelands is a useful strategy to document the capacity of the rangeland that could accommodate a given number of livestock species and to develop proper interventions for future pasture utilisation. The vegetation compositions of rangelands vary depending on topography, climate and soil fertility (Coppock, 1994). The current study was designed to characterize vegetation composition and grassland types as well as to estimate biomass production and carrying capacity of the rangeland in Ordolla areas of Shinile zone, eastern Ethiopia in which information is lacking for designing and implementing range and natural resources management and development interventions.

\section{Materials and Methods}

\subsection{General Description of the Study Area}

Ordolla is found in Shinile zone of the Somali Regional State of Ethiopia, $25 \mathrm{~km}$ north of Errer town and $12 \mathrm{~km}$ west of Aydora and $15-20 \mathrm{~km}$ south of Azbuli at an elevation of $820 \mathrm{~m}$, receiving 400-500 $\mathrm{mm}$ rainfall per annum with high temperature through out the day. The study covered an area $227 \mathrm{~km}^{2}$, about 22,651 ha of land. Ordolla area is classified as recent and pleistocene alluvium undifferentiated geologically and the soil is continental sediments including alluvium, aeolian deposits and eluvium differentiated 
into lacustrine deposits (Corra, 1993). There is wide alluvium expanding plain stripped by fast moving hydrographical net south of Errer in the direction of Awash Valley and Djibouti.

Ordolla Kebele (peasant Adminstration) and most of the settlements are located along the main Ordolla River that joins Asbuli river to the west, $20 \mathrm{~km}$ to the north of Ordolla. On east side, the biggest river is found crossing Aydora Kebele, coming from Tebi and Sedeti mountains and all the rivers in Ordolla areas are seasonal and do not have permanent flood. The hydro net, in addition of these main rivers, presented plenty of tributary rivers, hydromorphic veins and progressive gullies created by soil erosion (Map 1). The range land was mainly open grassland covered by short growth cycle annual vegetation which was originally predominant compared to woody stratus. Woody stratus was found in the southern part of the area on sandy soils near the hills surrounding Errer district but decreasing bit by bit when going to the north due to heavy grazing. The rangeland was mainly opened grassland covered by annual vegetation (Map 2).

\subsection{Study Procedures}

Vegetation and grassland characterization was done by interpretation and primary zoning of LANDSAT image based on the appearance of images and using GPS by clustering and delineation of similar grasslands and vegetation types together and taking samples of representative points to be surveyed. Twelve aerial photographs available for the area issued from the Ethiopian Mapping Agency (1: 50000) (edited 1999), Asbuli and Aydora topo maps (1:50000) (1999) and Dire Dawa geological map (1: 250000) (1985) were used during the field work (Map 1). During the field survey, visits were made to each representative grassland priory identified on LANDSAT image and moving to each site using GPS for validation in early October 2004. The latitude, longitude and altitude of the grasslands identified on the map were read on a hand held GPS during the fieldwork. The data include location, soil type, grazing land exploitation and grassland types, percentage of vegetation cover, grazing lands and barren soil, proportion of grasses, shrubs and trees and range and soil degradation.

\subsection{Vegetation Composition, Biomass Production and Carrying Capacity}

In the long rainy season of 2004, five half-hectare $(50 \mathrm{~m} \times 100 \mathrm{~m})$ pasture sites were enclosed in all direction around Ordolla village on degraded rangeland dominated by weeds and barren soil to sensitize livestock herders and authorities about the impact of overgrazing and to estimate vegetation composition and potential biomass production. For biomass yield estimation of the vegetation inside the enclosure, four samples of $1 \mathrm{~m} \times 1 \mathrm{~m}$ quadrates in each site, a total of 20 samples were taken randomly, in which all the herbaceous species were cut at full maturity. All the plant species inside the quadrat were harvested and weighed and samples dried in an Oven at $65^{\circ} \mathrm{C}$ for $72 \mathrm{~h}$ to constant weight for dry matter yield determination (Tarawali et al., 1995). In addition, in each grassland types and in the enclosures, all plant species were listed and identified on site primarily based on their morphological, structural and floristic characteristics while unknown species were collected for further identification at Haramaya University Herbarium in comparison with preserved specimens and using taxonomic keys (FAO, 1989; Hedberg and Edward, 1989; Sylvia, 1995).

In Ordolla areas, the rainfall pattern allows two vegetation growth cycles per year. The first rainy period called "Gu" which is the shortest one from mid-March to mid-May and "Karan" is the long rainy season from July to September. The enclosure biomass yield from the five random sites and 20 samples across Ordolla areas represented the Karan vegetation growth only, which is the main biomass production period. The $\mathrm{Gu}$ vegetation growth has not been assessed but elders in the community considers that the vegetation growth in $\mathrm{Gu}$ period is roughly half of the Karan season due to short and small rainfall even if the limitation in exactly estimating the biomass in $\mathrm{Gu}$ period is clear. Thus, the total vegetation productivity of the area was obtained by adding the GU season production onto the Karan season biomass production.

Estimation of livestock numbers grazing in Ordolla areas was done through community interview on average number of animals per household and number of household heads for each Kebele settlements and the TLU conversion factors for cattle, sheep and goats, donkey and camel which are $0.7,0.1,0.5$ and 1 , respectively (ILCA, 1990). The theoretical carrying capacity (CC) of a given grazing area is calculated as $\mathrm{CC}=\left(\mathrm{B}^{*} \mathrm{~K}\right) / \mathrm{PD} \times 6.25$ (Stoddart, 1976), in which B is the biomass edible in $\mathrm{kg} \mathrm{DM} / \mathrm{ha}, \mathrm{K}$ is the animal use ratio which varies between 0.1 and 0.9 but usually 0.3 is considered as the grazing lands has limit for pasture regeneration properly and $\mathrm{PD}$ is the period duration in days and 6.25 is $\mathrm{kg}$ of $\mathrm{DM}$ consumed by one TLU/day. The pasture available for livestock is only for 3 to 4 months in Ordolla areas and the two rainy seasons are separated by a short dry spell resulting in creating two short vegetation growth cycles which limits the amount and duration of biomass production. During this dry spell the pastoralists move and displace their cattle by remaining sheep and goats and donkey. Therefore, the CC adapted to the transhumant condition for cattle in Ordolla areas was calculated for two short rainy seasons.

Five composite soil samples of each $1 \mathrm{~kg}$ were collected from hydromorphic veins, upper sandy areas and eroded gullies separately which constitute a total 
of 15 samples. A composite sample was prepared at each sampling site for texture, $\mathrm{pH}$ (Bouyoucos, 1962), organic matter (Walkley and Black, 1934), total $\mathrm{N}$ (Jackson, 1970), available P, exchangeable $\mathrm{K}, \mathrm{Ca}, \mathrm{Mg}$ and $\mathrm{Na}$ (Olsen et al., 1954). Electrical conductivity was determined using sodium saturation ratio (SAR) as $[\mathrm{Na}+] / \sqrt{ } 1 / 2\left\{\left[\mathrm{Ca}^{2+}\right]+\left[\mathrm{Mg}^{2+}\right](\right.$ Van Reev Wijk, 1992) and the results of the soil test are presented in Table 1 and 2 .

\section{Results and Discussion}

\subsection{Grassland Distributions}

Seventeen grassland types are identified (Map 2) in Ordola areas based on soil type, vegetation structure and species composition according to vegetation classification of Pratt and Guwyanne (1977). The detail description of each grass land is indicated in Table 3 but some unique characteristics of each grassland type are discussed in brief as follows:

3.1.1. Barren Land with Scarce Caddaba rotundifolia and Restricted Pockets of Mixed Perennial and Annual Herbaceous (ORD 1)

The grassland was covered by barren land (95\%) with scattered shrubs (1\%) and perennial grasses (4\%). The dominant shrub was Caddaba rotundifolia and rare Seddera bagshawei and Cissus quadrangularis and the grass species were Brachiaria leersioides and Dactyloctenium scindicum.
3.1.2. Acacia nubica Open Shrub Land (ORD 2)

It was open shrub vegetation composed of Acacia nubica syn. Oerfota and rare Caddaba with 40 and $10 \%$ canopy cover, respectively, and some weeds along the shallow gullies.

3.1.3. Bushed Grassland Altered by Invading Species in Lower Hydromorphic Valley (ORD 3)

It was bushed grassland covered $40 \%$ by shrubs and 50 by various perennial grasses and $10 \%$ barren land. The grass species were Cynodon, Setaria pumila and $B$. leersioides and $C$. rotundifolia and some $S$. bagshawei and A. nubica were also found. The grassland was cinvaded by Xanthium strumarium, Solanum somalense and Parthenium hysterophorus.

\subsubsection{Tributary Riverbanks of Open Shrub-Land Dominated by Acacia Species and Annual Vegetation (ORD 4)}

It was open shrub grassland in riverbanks and hydromorphic valleys with barren land (50\%), shrubs (45\%) and $5 \%$ herbaceous vegetation. Acacia tortilis covered $40 \%$, A. nubica $(2 \%)$ and C. rotundifolia $(1 \%)$ and no grasses.

Table 1. Soil physical and chemical characteristics in Ordolla areas of Shinile zone, eastern Ethiopia

\begin{tabular}{|c|c|c|c|c|c|c|c|}
\hline \multirow[t]{2}{*}{ Description of the sampled area } & \multicolumn{3}{|c|}{ Texture $(\%)$} & \multirow{2}{*}{$\begin{array}{c}\mathrm{pH}-\mathrm{H}_{2} \mathrm{O} \\
(1: 2.5)\end{array}$} & \multirow[t]{2}{*}{$\mathrm{OM}(\%)$} & \multirow[t]{2}{*}{ Tot $\mathrm{N}(\%)$} & \multirow[t]{2}{*}{$\mathrm{EC}(1: 2.5)$} \\
\hline & Sand & Silt & Clay & & & & \\
\hline $\begin{array}{l}\text { Experimental enclosure } \\
\text { (hydromorphic vein.) }\end{array}$ & 27.12 & 36 & 36.88 & 7.86 & 1.53 & 0.06 & 0.27 \\
\hline $\begin{array}{l}\text { Experimental enclosure (upper } \\
\text { sandy part) }\end{array}$ & 63.12 & 20 & 16.88 & 7.94 & 0.54 & 0.02 & 0.21 \\
\hline Erosive gulley (degraded banks) & 87.12 & 2 & 10.88 & 7.89 & 0.25 & 0.01 & 0.13 \\
\hline
\end{tabular}

OM= Organic matter; EC=Eelectrical conductivity; Tot $N=$ Total nitrogen

Table 2. Some soil macro nutrients in Ordolla areas of Shinile zone, eastern Ethiopia

\begin{tabular}{lccccc}
\hline Description of the sampled area & $\begin{array}{l}\text { Available } \\
\mathrm{P}(\mathrm{ppm})\end{array}$ & Exch. Na & Exch. K & Exch. Ca & Exch. Mg \\
\cline { 2 - 6 } & & & \multicolumn{3}{c}{ Com0c kg $^{-1}$ soil } \\
\hline Experimental enclosure (hydromorphic vein.) & 5.12 & 0.37 & 1.40 & 43.73 & 4.92 \\
Experimental enclosure (upper sandy part) & 4.45 & 0.38 & 0.67 & 33.37 & 2.92 \\
Erosive gulley & 3.20 & 0.23 & 0.29 & 25.36 & 1.70 \\
$\quad$ (degraded banks) & & & & &
\end{tabular}

Exch = Exchangeable $; P=$ Phosphorus $; \mathrm{Na}=$ Sodium $; \mathrm{K}=$ Potassium $; \mathrm{Mg}=$ Magnesium 


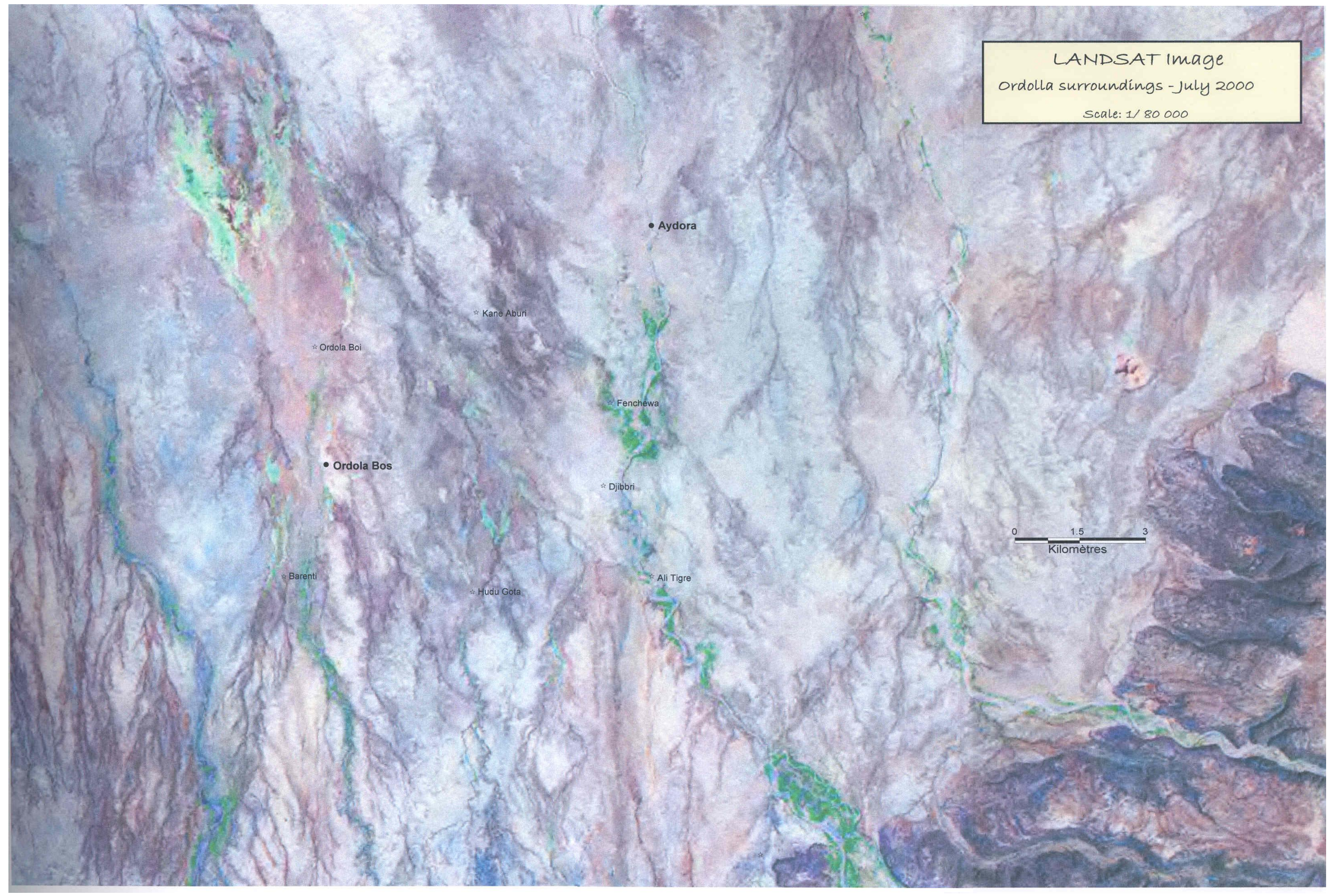

Map 1. LANDSAT Image of Ordolla surroundings, Somali Regional State, eastern Ethiopia 


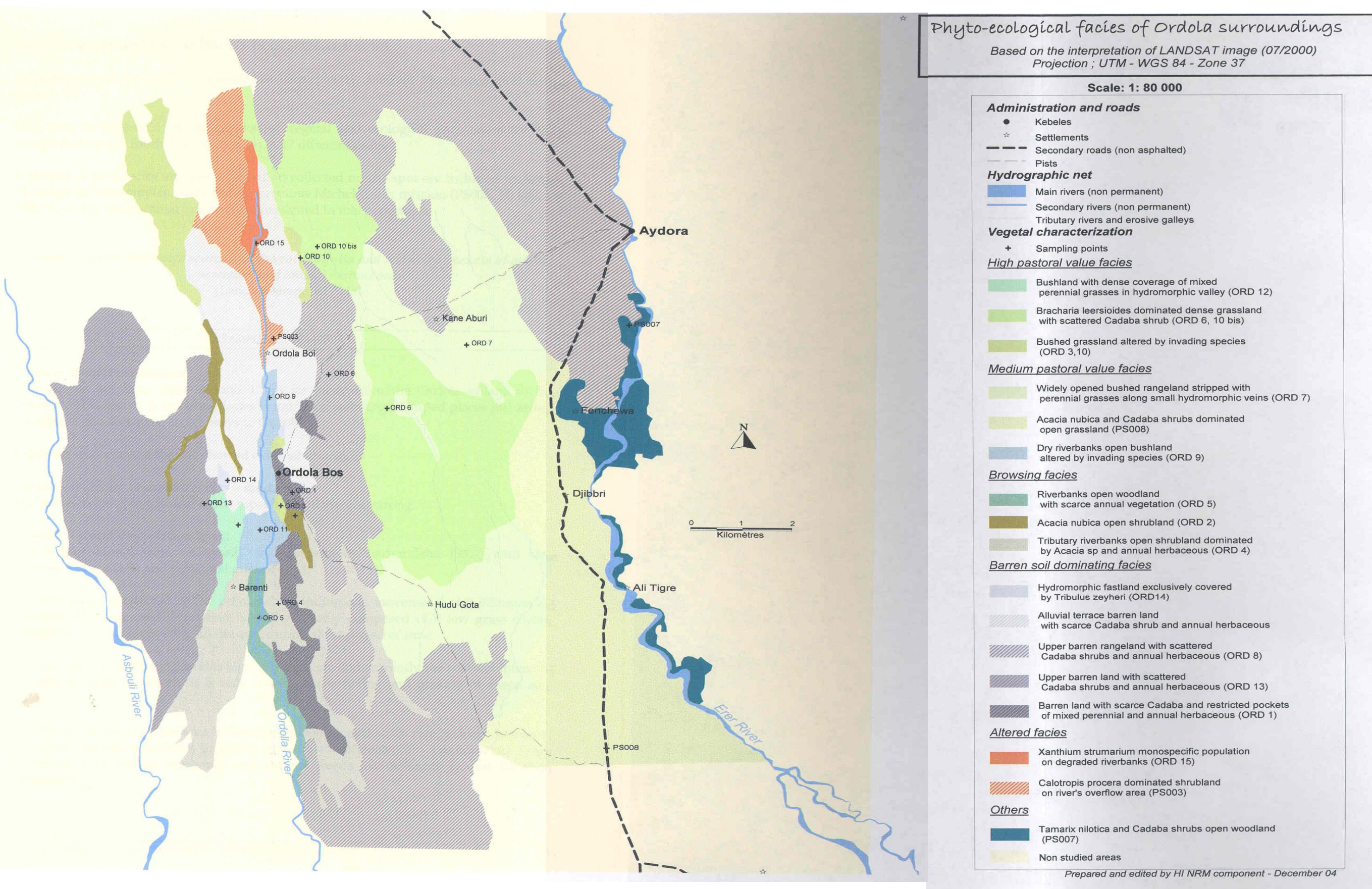

Map 2 Phyto-ecological grasslands of Ordolla areas in Shinile zone of Somali Regional State, eastern Ethiopia 
3.1.5. Riverbanks Open Woodland with Scarce Annual Vegetation (ORD 5)

The grassland covered $40 \%$ barren soil and 40-45\% woody vegetation especially Acacia seyal (10\%) and grouped C. rotundifolia (20\%) and few Balanites aegyptiaca along the riverbanks with $10 \%$ T. zeyheri but no perennial grasses.

3.1.6. B. leersioides Dominated Dense Grassland with Scattered C. rotundifolia Shrub (ORD 6)

It was typical grassland $80 \%$ covered by perennial grasses with $C$. rotundifolia (15\%) and 5\% barren soil and the grass species was B. leersioides $(70 \%)$ and Cynodon species (10\%). Next to this grassland, about 4$5 \mathrm{~km}$ far from Ordolla village to the north east direction there was grassland represented by ORD 10 BIS dominated by $B$. leersioides $(70 \%)$ and Dichantium annulatum (5\%), Cyperus species (10\%) and Caddaba glandulosa $(15 \%)$.

3.1.7. Widely Opened Bushed Rangeland Striped with Perennial Grasses along Small Hydromorphic Veins (ORD 7)

This grassland was composed of two sub-grasslands: the long veins formed due to hydromorphic conditions and presented various perennial and annual grass mixed with weeds and the interfluves between hydromorphic veins were the upper land with dry and barren soil covered by scattered $C$. rotundifolia and $T$. zeyheri.

3.1.8. Upper Barren Rangeland with Scattered $C$. rotundifolia and Annual Vegetation (ORD 8)

It was covered $95 \%$ by barren land and $5 \% C$. rotundifolia canopy cover. T. Zeyheri was only covering most of the barren land during the rainy season.

\subsubsection{Dry Riverbanks Open Bush Land Altered by} Invading Species (ORD 9)

The vegetation was covered by $C$. rotundifolia with $40 \%$ canopy cover, grouped in big and full pockets but it was increasing in size. The vegetation area was covered with $40 \%$ barren soil and the rest 20 and $20 \%$ covered with herbaceous layer and $X$. strumarium, respectively.

3.1.10. Bushed Grassland Altered by Invading Species in Lower Hydromorphic Valley (ORD 10)

It was covered $90 \%$ vegetation and $10 \%$ barren land and the vegetations were $C$. rotundifolia $(20 \%)$ and S. bagshawei, stunted Acacia seyal and mixture of B. leersioides and Cynodon nlemfuensis (20\%) and it was coveed by Xanthium strumarium (20\%), Parthenium hysterophorus (20\%) and Solanum species $(10 \%)$.
3.1.11. Bush Land with Dense Coverage of Mixed Perennial Grasses in Hydromorphic Valley (ORD 12)

It represented the highest productive vegetation covered by shrubs and perennial grasses $(80 \%)$. It was divided into two parts: the central one where the vegetation coverage was around $100 \%$ of which $D$. annulatum, $B$. leersiodes and Ischaemum afrum cover $50 \%$ and A. seyal and $C$. rotundifolia covered the remaining 50\% canopy cover and the peripheral part of this vein was covered by $B$. leersioides and $C$. rotundifolia with 20 and 40 canopy cover, respectively.

3.1.12. Upper Barren Land with Scattered $C$. rotundifolia Shrub and Annual Herbaceous on Gravelled Soil (ORD 13)

The vegetation was covered $90 \%$ by barren soil and 5 to $10 \%$ scattered $C$. rotundifolia.

3.1.13. Hydromorphic Fast Land Covered by Tribulus zeryheri (ORD 14)

The vegetation was highly influenced by hydromorphic condition and covered only by barren soil without grasses but it was covered by $T$. zeyheri during the rainy season.

\subsubsection{Xanthium strumarium Monospecific} Formation on Degraded Riverbanks (ORD 15)

The vegetation area was characterized by $30 \%$ barren soil land and exclusively covered $65 \%$ by $X$. strumarium and $5 \%$ by $C$. procera but no herbaceous species at all.

\subsubsection{Calotropis procera Dominated Shrub Land on} River Overflow Area (ORD 15)

The vegetation was dominated by tall and densely populated $C$. procera, followed by $X$. strumarium, Amaranthus hybridus, $S$. somalense and $P$. hysterophorus, respectively.

3.1.16. Alluvial Terrace Barren Land with Scarce Caddaba Shrub and Annual Vegetation

This vegetation was dominated $15 \%$ by Caddaba species and $85 \%$ by barren land and some pockets of $T$. zeyheri.

3.1.17. Acacia and Caddaba Dominated Open Vegetation (PS 008)

This vegetation was characterized by distinct patches of A.oerfota, $C$. rotundifolia and $T$. nilotica and the presence of rare Barleria eranthemoides, Lasiocorys abyssinica, C. quadrangularis and stunted Panicum coloratum, Chrysopogon plumulosus and Eragrostis cilianensis. 


\subsubsection{Tamarix nilotica and Caddaba Dominated Open Vegetation (PS 007)}

It was characterized by distinct patches of $C$. rotundifolia and $T$. nilotica and the presence of rare Aerva jsvanica, L. abyssinica, Solanum indicum, S. somalense, and Abutilon figarianum, Cissus quadrangularis and some stunt $P$. coloratum, $C$. plumulosus, Setaria pumila, E. cilianensis and Dactyloctenium scindicum.

\subsection{Ranking of Vegetation Types}

The grassland types were ranked into six pastoral values (Map 3) based on area coverage of palatable species mainly perennial grasses, species diversity and productivity of the pasture follows: -

\subsubsection{High Pastoral Value Grassland}

It covered 3275 ha (14.4\%) representing the best pastures of the area including pure vegetation (ORD 6), the mixed vegetation (ORD 10) and the very productive grass and bush mixed land (ORD 12). These are the most productive rangelands because of more than $80 \%$ perennial vegetation coverage. Moreover, this vegetation was mainly composed of dense perennial grass carpet (ORD 6 and 10) except in the small over trampled part (central part of hydromorphic veins, depressions-ORD 10).

\subsubsection{Medium Pastoral Value Grassland}

It covered 5361 ha $(23.6 \%)$ of Ordolla area and it included the hydromorphic vein vegetation (ORD 7), the close alluvial terrace (ORD 9) and the open shrub and vegetation (PS008). They were areas where some perennial and annual mixed grasses and weeds species were found in relatively dense coverage (ORD 7 and more weeds in ORD 9). It also included the PS008 grassland where only annual grasses and $T$. zeyheri were found but constituted an interesting potential area by its wide coverage and the presence of some Acacia shrubs. However, these rangelands have quite lower pastoral interest than the first group, as the vegetation coverage was limited to restricted areas (hydromorphic veins) or pockets (PS008).

\subsubsection{Preferred Shrubs Dominated Grassland}

It covered 1561 ha (almost $6.9 \%$ ) of Ordolla area and included all woody grasslands dominated by $A$. nubica syn oerfota, along the tributary riverbeds. The herbaceous coverage was absent or limited (ORD 2, 4, 5 ) and mainly composed of $T$. zeyheri and some rare annual grasses in secondary erosive gullies. These grasslands have limited potential due to the absence of grass and even herbaceous species but have pastoral interest as they constitute an important browse for camels.

\subsubsection{Barren Soil Dominated Grassland}

It occupied 11418 ha (almost 50.4\%) of Ordolla area representing ORD 1, 8, 13, 14 and the wide terrace. The contribution of these grasslands to grazing was very low to null as they were covered by more than $90 \%$ barren soil and $10 \%$ by Caddaba shrubs. Some of the barren soil was completely sterile, but remaining wide areas covered by $T$. Zeheri, the only vegetation growing for few weeks. Due to its short-lived behaviour of $T$. Zeheri, it is partially grazed by camels before blooming. Therefore, these grasslands are not considered as significant grazing lands.

\subsubsection{Altered and Degraded Grassland}

This grassland covered 606 ha (almost 2.7\%) of Ordolla area representing grasslands invaded by $C$. procera (PS003) and $X$. strumarium (ORD 15) where they were forming pure colony. These grasslands were located along the river, where trampling by animals during watering and do not have interest for animal grazing since there are no perennial grasses and preferred browse species.

\subsubsection{T. nilotica Formation}

It covered 400 ha (almost $1.8 \%$ ) of Ordolla area. This vegetation (PS007) was isolated as it was pure population of $T$. nilotica. Moreover, it does have small value for grazing since there is no herbaceous species for animals.

\subsection{Grazing Land Categorization}

According to the ranking done, the grazing areas in Ordolla surroundings are categorized by considering the surveyed areas as a whole, based on the palatability of herbaceous vegetations (proportion of perennial grasses, shrubs and invaders available), total vegetal coverage and barren soil as follows:

1. Good and permanent grazing which represents only $15 \%$ of the surveyed area (grasslands of the first ranked group)

2. Complementary grazing lands, which represent additional $30 \%$ (medium pastoral value + browsing grassland), wide areas dominated by low productive barren soil as well as taking probably low part on livestock grazing

3. About $55 \%$ of the rangeland can be considered as non-grazing areas (barren soil dominated grassland + altered grassland + Tamarix colony) due to their limited values and it does have low value for livestock grazing or browsing. 


\subsection{Vegetation Composition, Biomass Production and Carrying Capacity}

After enclosing the pasture, the difference between the inside and outside on vegetation composition was very clear and demonstrative. Although the place was looking degraded, barren, sandy and invaded by weeds, the grasses grown showed an unforeseen diversity and density. By protecting seasonal grazing, essential grass species has grown up, flowered and set seeds with in short period demonstrating high capacity of regeneration and presence of good soil seed bank. Moreover, it was impressive for herders to observe the grasses at full maturity as grasses were continuously grazed even up to the roots in the unprotected area. This showed that the area has good potential and capacity to support different livestock species if properly managed. The main grass species observed in the enclosure were Cynodon dactylon, Cynodon nlemfuensis, Andropogon greenwayii, Brachiaria leersiodes, Setaria pumula and Cenchrus ciliaris in order of abundance and rarely Cyprus involucratus Table 3. Enclosures are good sources of biodiversity of grass and shrub vegetations as indicated by different authors (Blench and Sommer, 1999; Emiru, 2002). The grasses are naturally palatable and important for livestock feeding and the height of these grasses reached around $25-50 \mathrm{~cm}$. Similar research findings are reported by many authors in other parts of Ethiopia (Coppock, 1994; Baars, 1996; Ayana and Baars, 2000; Lema, 2001; Amsalu and Baars, 2002; Alemayehu, 2004; Yihalem, 2004; Yvan and Tessema, 2005).

Biomass produced measured inside the enclosure during the main rainy season was $4.5 \mathrm{t} \mathrm{DM} / \mathrm{ha}$. This biomass yield was obtained in the Karan rainy season (July to September) only herbaceous species due to the absence of trees and shrubs in the enclosure. The total grazing land annual biomass production in Ordolla areas may be estimated as $4.5+2.25=6.75 \mathrm{t}$ $\mathrm{DM} / \mathrm{ha} /$ year by taking the two short rainy seasons. This figure is comparable to most managed natural pasture (Tessema, 2005) and even higher than most of the communally grazed pasture in Ethiopia as reported by many authors (Coppock, 1994; Ayana and Baars, 2000; Lema, 2001; Amsalu and Baars, 2002). The productivity estimation for high pastoral value grazing lands, with no grass cover was 3275 ha $* 6.75 \mathrm{t} \mathrm{DM} / \mathrm{ha}$ $=22106 \mathrm{t} \mathrm{DM} /$ year and for medium pastoral value grazing lands, with $15 \%$ herbaceous cover was 5361 ha $* 0.15 * 6.75 \mathrm{t} \mathrm{DM} / \mathrm{ha}=5428 \mathrm{t} \mathrm{DM} /$ year, and the total annual biomass produced by different grazing lands in Ordolla areas was estimated to be around $27534 \mathrm{t}$ $\mathrm{DM} /$ year.

For the 390 households in twelve settlements in the Ordolla areas, the number of different animal species was estimated as follows: shoats 39 340, cattle 11 396, camels 3293 and donkey 315, total of 54344 heads of mixed livestock or 15361.7 TLU (Table 4). According to the estimated biomass production of the pasture and available livestock species in TLU, the carrying capacity of the rangeland in Ordola areas would be estimated as $0.16 \mathrm{TLU} / \mathrm{ha} /$ year $(27534000 * 0.3 / 365 *$ $6.25)$ or 6.25 ha grazing land for $1 \mathrm{TLU}$ or 1 camel or 10 shoats without affecting vegetation composition and pasture productivity. The estimated carrying capacity of Ordolla areas with respect to transhumant pastoral condition was 0.06 and $0.09 \mathrm{TLU} / \mathrm{ha}$ in dry (5 months) and in wet seasons (7 months), respectively.

\section{Conclusions}

In general, large proportion of Ordolla rangelands was barren land without herbaceous vegetation except some scattered shrubs and trees. Seventeen grassland types were identified in Ordola areas. Vegetation composition, grassland types and other phyto ecological characteristics of other districts of Shinile zone near Ordola area has been reported by Corra (1993). The dominant grass species in Ordolla areas were $C$. dactylon, C. nlemfuensis, E. cilianensis, C. ciliaris, A. greenwayii, B. leersiodes, S. pumila and Sorghum arundinaceum. A. tortilis, A. nilotica, A. mellifera and A. seyal were the most dominant shrubs with scattered C. rotundifolia, C. furmosa, S. bagshawei, T. nilotica, $D$. glabra and abundant $P$. hysterophorus, $C$. rotundifolia and $C$. quadrangularis. The grass biomass estimated in enclosure near Ordolla village was $4.5 \mathrm{t}$ $\mathrm{DM} / \mathrm{ha} / \mathrm{yr}$ and total annual biomass produced in Ordolla rangeland was around $27534 \mathrm{t} \mathrm{DM} / \mathrm{year}$. The theoretical and transhumant context carrying capacities of Ordolla rangeland in dry and wet seasons were 0.16, 0.06 and $0.09 \mathrm{TLU} / \mathrm{ha}$, respectively without affecting the pasture. There were good grazing lands in hydromorphic depression in Ordolla areas but the palatable grasses, trees and shrubs are decreasing due to overgrazing, runoff and drought and replaced by Parthenium, Calotropis, Solanum and Xanthium species, which are invader plant species and replaced palatable plants (decreasers and increasers mainly perennial grasses) indicating overgrazing and rangeland degradation as observed in most parts of Ethiopia.

\section{Acknowledgment}

The authors would like to thank Handicap International for financing the study and Haramaya University for the expertise and the pastoralists for their assistance during the fieldwork. 
Table 3. Description of different grassland types in Ordolla areas of Shinile zone, eastern Ethiopia

\begin{tabular}{|c|c|c|c|c|c|c|c|c|c|}
\hline \multirow{3}{*}{$\begin{array}{l}\text { Vegetation } \\
\text { types code }\end{array}$} & \multicolumn{9}{|c|}{ Vegetation type descriptions } \\
\hline & \multirow{2}{*}{$\begin{array}{l}\text { Area covered } \\
\text { (ha) }\end{array}$} & \multirow{2}{*}{$\begin{array}{l}\text { Altitud } \\
\text { (masl) }\end{array}$} & \multicolumn{2}{|c|}{ Proportion of } & \multirow{2}{*}{$\begin{array}{l}\text { Drainage } \\
\text { pattern }\end{array}$} & \multirow{2}{*}{$\begin{array}{l}\text { Estimated } \\
\text { field texture }\end{array}$} & \multirow{2}{*}{$\begin{array}{l}\text { Hypochloride } \\
\text { Test }\end{array}$} & \multicolumn{2}{|c|}{ Vegetation } \\
\hline & & & Vegetation & Barren soil & & & & Use level & Pastoral interest \\
\hline ORD1 & 417 & 827 & 5 & 95 & External & Silty sand & Strong efferscence & High to very high & Quasi in existent \\
\hline ORD2 & 147 & 823 & 50 & 50 & External & Silty & Strong efferscence & Very high & Low \\
\hline ORD3 & 486 & 808 & 90 & 10 & External & Silty & Strong efferscence & Medium & Very high \\
\hline ORD10 & - & 800 & 90 & 10 & External & Silty & Strong efferscence & Low & Very high \\
\hline ORD4 & 1208 & 824 & 50 & 50 & External & Silty clay & Strong efferscence & High & High to very high \\
\hline ORD5 & 207 & - & 60 & 40 & External & Silty clay & Strong efferscence & Very high & Low \\
\hline ORD6 & 2604 & 800 & 95 & 5 & external & Sand silty & Strong efferscence & Low & Very high \\
\hline ORD10B15 & - & 790 & 95 & 5 & External & Sand silty & Strong efferscence & Low & Very high \\
\hline ORD7 & 2891 & 804 & 10 & 90 & External & Clay & Strong efferscence & High & Low \\
\hline ORD8 & 7160 & 802 & 5 & 95 & External & Silty clay & Strong efferscence & Very high & Low \\
\hline ORD9 & 279 & 800 & 60 & 40 & External & Silty sand & Strong efferscence & Very high & low \\
\hline ORD12 & 133 & 814 & 80 & 20 & External & Clay silt & Strong efferscence & Medium & Very high \\
\hline ORD13 & 2505 & 822 & 10 & 90 & external & Sandy clay & Strong efferscence & In existent & Very low \\
\hline ORD14 & 20 & - & 5 & 95 & External & Silty-clay & Strong efferscence & Very high & Very low \\
\hline ORD15 & 103 & 817 & 70 & 30 & External & Silty loam & Strong efferscence & Very high & in existent \\
\hline ORD5 \& 9 & 1317 & - & 20 & 80 & External & Silty & Strong efferscence & Very high & Low to null \\
\hline PS008 & 2243 & 863 & 40 & 60 & External & - & Strong efferscence & High & Low \\
\hline PS007 & 400 & 802 & 35 & 65 & External & Clay & Strong efferscence & High & Low \\
\hline
\end{tabular}

Table 4. Vegetation composition of Ordolla areas of Shinile zone, eastern Ethiopia

\begin{tabular}{|c|c|c|}
\hline Caesalpiniodeae & Gramineae & Convolvulaceae \\
\hline Cassia italica (Mill.) & Andropogon greenwayii Napper & Seddera bagshawei Rendel \\
\hline Senna Alexandria (L.) Link & Brachiaria leersioides (Hochst.) Stapf & Seddera hallieri Engl. and Pilgr \\
\hline Tamarindus indica $\mathrm{L}$. & Cenchrus ciliaris $\mathrm{L}$. & Seddera latifolia Steud. \\
\hline Papilionoideae & Chryspogon plumulosus Hochst. & Cactaceae \\
\hline Crotalaria spinosa Benth & Cynodon dactylon (L.) pers & Opuntia ficus indica \\
\hline Indigofera amorphoides & Cynodon nlemfuensis Vanderyst & Cyperaceae \\
\hline Salvadoraceae & Dactyloctenium scindicum Boiss & Cyprus involucratus Rottb. \\
\hline Dobera glabra (Forsk.) Juss. & Eragrostis cilianensis (All.) Link & Euphorbiaceae \\
\hline Mimosoideae & Setaria pumila (Poir.) Roem. & Euphorbia tirucali L. \\
\hline Acacia horrida (L.) Willd Subsp. & Sorghum arundinaceum (Willd). Stapf & Solanaceae \\
\hline Acacia mellifera (Vahl) Benth & Sporobulus ioclades (Tri.) Nees & Datura stramonium $\mathrm{L}$. \\
\hline Acacia nilotica (L. Del. Subsp. & Tamaricaceae & Solanum indicum L. \\
\hline Acacia senegal (L.) Willd. & Tamarix nilotica (Ehrenb.) Bunge & Solanum somalense Franchet \\
\hline Acacia seyal Del. Var. seyal & Tiliaceae & Vitaceae \\
\hline Acacia tortilis (Forssk.) Hayne & Grewia bicolour Juss & Cissus qudrangularis L. \\
\hline Balanitaceae & Grewia erythraea Schweinf. & Cisus rotundifolia (Forssk.) Vahl \\
\hline Balanites aegyptica (L.) Del & Grewia tenax (Forssk.) Fiori & Amaranthaceae \\
\hline Balanites glabra Mildbr. & Grewia villosa Willd & Amaranthus hybridus L. \\
\hline Capparaceae & Salvadoraceae & Compositeae \\
\hline Caddaba farinose Forssk. & Dobera glabra (Forsk.) Juss. & Parthenium hysterophorus \\
\hline Caddaba glandulosa Forssk. & Convolvulaceae & Vernonia cinerascens Sch. Bip. \\
\hline Caddaba heterotricha Stocks. & Seddera bagshawei Rendel & Xanthium strumarium auc. Non L. \\
\hline \multirow[t]{2}{*}{ Caddaba rotundifolia Forssk } & Seddera hallieri Engl. And Pilgr & Verbenaceae \\
\hline & Seddera latifolia Steud. & Lantana camara $\mathrm{L}$. \\
\hline
\end{tabular}




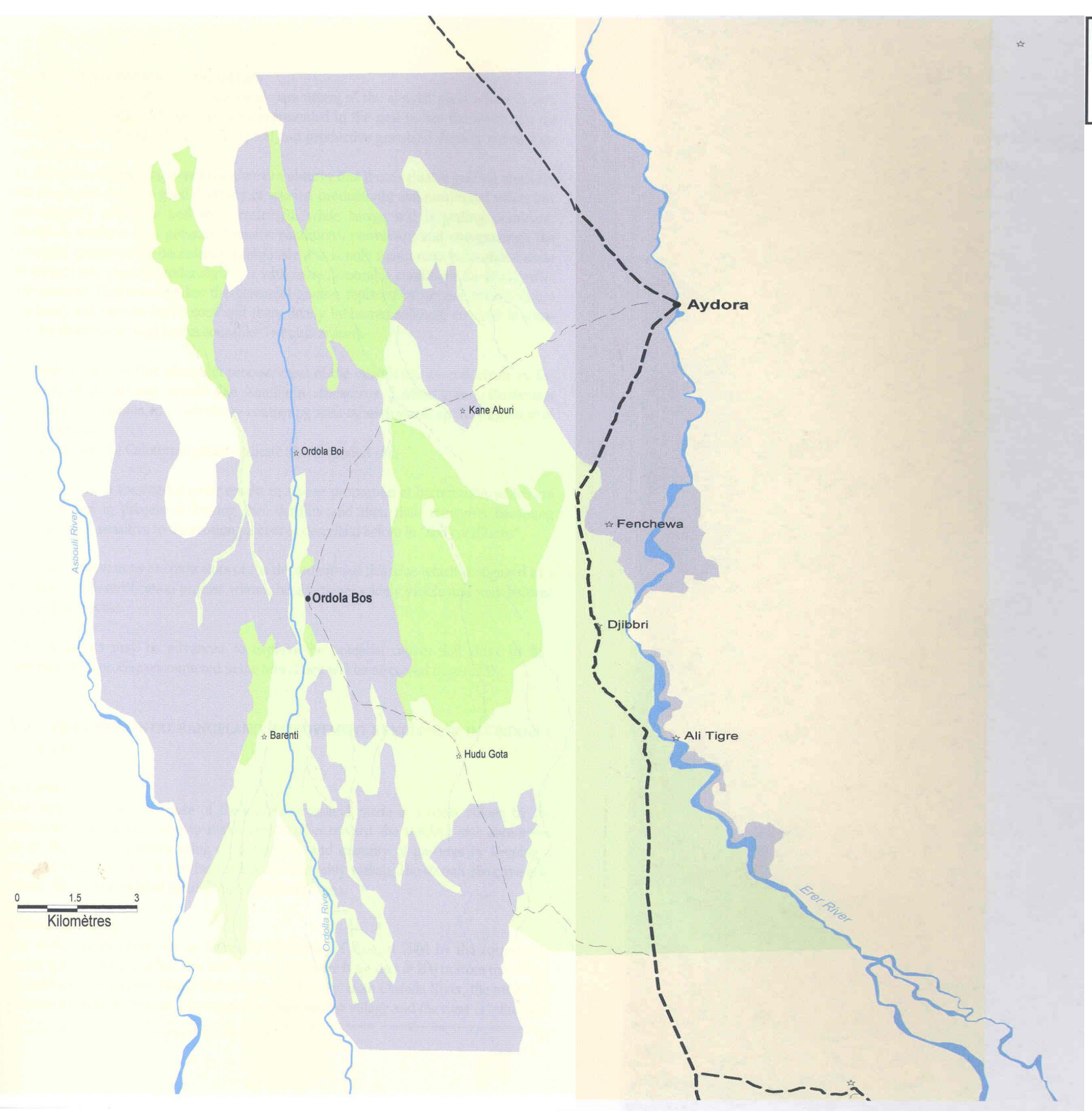

Map of grazing areas

in ordolla surroundings

Pulled out from PE map

Based on the interpretation of LANDSAT image (07/2000) Projection : UTM - WGS 84 - Zone 37

$\stackrel{N}{\Lambda}$

Scale: 1: 80000

General
Kebeles
Main rivers (non permanent)
Secondary rivers (non permanents)
Tributary rivers and erosive galleys

Thematic

Grasslands $-3275 \mathrm{Ha}-(14 / 100)$

( $>80 / 100$ of perennial grass coverage)

Complementary grazing lands - $6922 \mathrm{Ha}-(38 / 100)$ (restricted areas of various herbaceous or tree

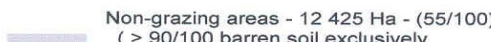
barren soil exclusively
cadaba $<10 / 100$ and

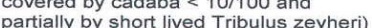
Non studied areas 
Table 5. Average and total of number of livestock species in Ordolla areas of Shinile zone, eastern Ethiopia

\begin{tabular}{|c|c|c|c|c|c|c|c|}
\hline \multicolumn{8}{|c|}{ Number of livestock species per household (HH) } \\
\hline & $\begin{array}{l}\text { Poor group } \\
(70 \%)\end{array}$ & Medium & $p(15 \%)$ & Better off & $(15 \%)$ & Total heads & TLU \\
\hline Cattle & $0-7 \quad 273 \mathrm{HH}$ & $20-40$ & $58 \mathrm{HH}$ & $100-200$ & $58 \mathrm{HH}$ & 11396 & 7977 \\
\hline Shoats & $30-50$ & $60-120$ & & $300-500$ & & 39340 & 3934 \\
\hline Camel & $0-5$ & $15-30$ & & $80-120$ & & 3293 & 3293 \\
\hline \multicolumn{6}{|c|}{ Total } & 54344 & 15361.7 \\
\hline
\end{tabular}

\section{References}

Adane, K. 2003. Effect of stage of growth and fertiliser application on dry matter yield and quality of natural grasslands in the highlands of north Shoa, Oromia Region. M.Sc. Thesis. Alemaya University, Alemaya, Ethiopia.

Adane, K. and Berhan, T. 2005. Effect of harvesting frequency and nutrient levels on natural pasture in the central highlands of Ethiopia. Tropical Science 45: 77-82.

Alemayehu, M. 1998. The Borana and the 1991-1992 droughts. A rangeland and livestock resources study. Addis Ababa, Ethiopia.

Alemayehu, M. 2004. Rangeland biodiversity: Concepts, approaches and the way forward. Addis Ababa, Ethiopia. pp. 161.

Amsalu, S. and Baars, R.M.T. 2002. Grass composition and rangeland condition of the major grazing areas of the mid rift valley, Ethiopia. African Journal of Range and Forage Science 19: 161166.

Ayana, A. 1999. Range condition and traditional grazing management in Borana. M.Sc. Thesis, Alemaya University of Agriculture, Alemaya, Ethiopia

Baars, R.M.T., Chileshe, E.C. and Kalokoni, D.M. 1996. Range condition in high cattle density areas in western province of Zambia. Tropical Grasslands 31:569-573.

BLDP (Borona Lowland Pastoral Development Programmes). 2004. Overview of Borona pastoral production livelihood system. Extension - PRA - and M + E - concepts Networking and policy advocacy. BLPDP, Documentation on 7 years experience, Vol. I. December, 2004. Addis Ababa, Ethiopia.

Blench, R. and Sommer, F. 1999. Understanding rangeland biodiversity. Overseas Development Institute, Portland house, stage plane, London. Working paper. pp.121.

Bouyoucos, G.J. 1962. Hydrometer method improved for making particle size analysis of soils. Agronomy Journal 54:464-4
Bray, R.H and Kurtz, L.T. 1945. Determination of total organic and available forms of phosphorous in soil. Soil Science Society of America Proceedings 59: 39-45.

Coppock, D.L. 1994. The Borona Plateau of Southern Ethiopia: Synthesis of pastoral research, development and change, 1980-91. International livestock Centre for Africa, Addis Ababa, Ethiopia.

Corra, M. 1993. Ecological studies of three main rangelands of Ethiopia. Proceedings of a workshop on environmental monitoring and natural resources protection. Addis Ababa, Ethiopia.

Emiru, B. 2002. Actual and postural contribution of enclosures to enhance biodiversity in dry land of Eastern Tigray, with particular emphasis on woody plants. SLU (Swedish University of Agricultural Sciences), Sweden.

FAO. 1989. Weed Identification Guide for Ethiopia. Food and Agriculture Organization of the United Nations (FAO), Rome, Italy.

Jackson, M.L. 1970. Soil chemical analysis prenstice Hall, Inc, Engle Wood Cliffs. New Jersey.

Lemma, Z. 2001. Revegetation of degraded rangelands in middle Awash of Afar region with Cenchrus ciliaris and Chloris gayana. M.Sc. thesis, Alemaya University, Alemaya, Ethiopia.

Olsen, S.R., Cole, C.V., Watanable, F.S. and Dean,. L.A. 1954. Estimation of available phosphorus in soil by extraction with sodium bicarbonate USDA, Circ 939.

PFE (Pastoralists Forum Ethiopia). 2004. Pastoralism and sustainable pastoral development. Proceedings of the third national conference on pastoral development in Ethiopia. Addis Ababa, Ethiopia, 23-24 December 2003, Pastoralists Forum Ethiopia.

Pratt, D.T. and Guwynne, M.D. 1977. Rangeland Management ecology in East Africa. Hunder and Stoughton, London, UK.

SORPARI. 2003. Somali Region Pastoral and Agro pastoral Research Institute Research Master Plan. Small ruminant research technical Report (Final). Jijiga, Ethiopia. 
Stoddart, L.A., Smith, A.D. and. Box, T.W. 1975. Range management, McGraw-Hill book Co. New York, UK.

Sylvia, P. 1995. Flora of Ethiopia: Poaceae (Gramineae). In: Hedberg, I. and Edwards, S. (eds). Addis Ababa, Ethiopia/Uppsala, Sweden. Vol. 7. pp. 420.

Tessema, Z. 2005. Identification of indigenous pasture and the effect of time of harvesting and nitrogen fertiliser in the north-western Ethiopian highlands. Tropical Science 45: 73-77.

Van Reeu Wijk, L.P. 1992. Procedures for soil analysis $3^{\text {rd }}$ ed. International Soil Reference Centre Wageningen (ISRIC). The Netherlands, Wageningen

Walkley, A. and Black, C.A. 1934. An examination of wet digestion method for determining soil organic matter and proposed modification of the chromic acid titration method. Soil Science 37: 29-38

Yvan, O. and Tessema, Z. 2005. An assessment of grazing lands potentialities in Ordola surroundings (Erer districts) of Shinile zone. Handicap International, Dire Dawa, Ethiopia. pp. 75 . 